\title{
Anti-inflammatory effects of cell-based therapy with tyrosine hydroxylase-positive catecholaminergic cells in experimental arthritis
}

\author{
Zsuzsa Jenei-Lanzl, ${ }^{1}$ Silvia Capellino, ${ }^{1,2}$ Frieder Kees, ${ }^{3}$ Martin Fleck, ${ }^{1}$ Torsten Lowin, ${ }^{1}$ \\ Rainer H Straub ${ }^{1}$
}

\begin{abstract}
Handling editor Tore K Kvien
- Additional material is published online only. To view please visit the journal online (http://dx.doi.org/10.1136/ annrheumdis-2013-203925).

${ }^{1}$ Department of Internal Medicine I, University Hospital Regensburg, Regensburg,

Bavaria, Germany

${ }^{2}$ Division of Endocrinology,

Department of Pediatrics,

Johns Hopkins University

School of Medicine, Baltimore,

Maryland, USA

${ }^{3}$ Department of Pharmacology

and Toxicology, University

Regensburg, Regensburg,

Bavaria, Germany
\end{abstract}

\section{Correspondence to}

Dr Rainer H Straub, Laboratory of Experimental Rheumatology and Neuroendocrine Immunology, Department of Internal Medicine, University Hospital Regensburg, Biopark I, Josef Engert Str. 9,

Regensburg, Bavaria 93053,

Germany;

rainer.straub@ukr.de

Received 10 May 2013

Revised 10 September 2013

Accepted 10 November 2013

Published Online First

2 December 2013

\section{ABSTRACT \\ Objectives Studies in rheumatoid arthritis (RA), osteoarthritis (OA) and mice with arthritis demonstrated tyrosine hydroxylase-positive $\left(\mathrm{TH}^{+}\right)$cells in arthritic synovium and parallel loss of sympathetic nerve fibres. The exact function of $\mathrm{TH}^{+}$cells and mode of $\mathrm{TH}$ induction are not known.}

Methods Synovial cells of RA/OA were isolated and cultured under normoxic/hypoxic conditions with/without stimulating enzyme cofactors of $\mathrm{TH}$ and inhibitors of $\mathrm{TH}$. We studied TH expression and release of cytokines/ catecholamines. In vivo function was tested by cell therapy with $\mathrm{TH}^{+}$neuronal precursor cells $\left(\mathrm{TH}^{+}\right.$neuronal cells) in DBA/1 mice with collagen type II-induced arthritis (CIA).

Results Compared with normoxic conditions, hypoxia increased TH protein expression and catecholamine synthesis and decreased release of tumour necrosis factor (TNF) in OA/RA synovial cells. This inhibitory effect on TNF was reversed by TH inhibition with $\alpha$-methylpara-tyrosine ( $\alpha \mathrm{MPT})$, which was particularly evident under hypoxic conditions. Incubation with specific $\mathrm{TH}$ cofactors (tetrahydrobiopterin and $\mathrm{Fe}^{2+}$ ) increased hypoxia-induced inhibition of TNF, which was also reversed by $\alpha M P T$. To address a possible clinical role of $\mathrm{TH}^{+}$cells, murine $\mathrm{TH}^{+}$neuronal cells were generated from mesenchymal stem cells. $\mathrm{TH}^{+}$neuronal cells exhibited a typical catecholaminergic phenotype. Adoptive transfer of $\mathrm{TH}^{+}$neuronal cells markedly reduced CIA in mice, and 6-hydroxydopamine, which depletes $\mathrm{TH}^{+}$cells, reversed this effect.

Conclusions The anti-inflammatory effect of $\mathrm{TH}^{+}$ neuronal cells on experimental arthritis has been presented for the first time. In RA/OA, $\mathrm{TH}^{+}$synovial cells have TH-dependent anti-inflammatory capacities, which are augmented under hypoxia. Using generated $\mathrm{TH}^{+}$ neuronal cells might open new avenues for cell-based therapy.

\section{INTRODUCTION}

During the last two decades, neuroendocrineimmune interactions became more and more relevant in understanding pathophysiology of rheumatic diseases. ${ }^{1-5}$ For example, the actual target of inflammation in rheumatoid arthritis (RA), the synovial tissue, is strongly affected by the sympathetic nervous system depending on the phase of inflammation. In the early acute phase of experimental arthritis, the sympathetic nervous system has a pro-inflammatory role, ${ }^{6-8}$ whereas in the late chronic phase anti-inflammatory effects have been described. ${ }^{8}$ At the beginning of the chronic phase, the loss of sympathetic nerve fibres in synovial tissue was reported, which is paralleled by appearance of tyrosine hydroxylase-positive $\left(\mathrm{TH}^{+}\right)$ catecholamine-producing cells. ${ }^{9-12}$ Recently, these $\mathrm{TH}^{+}$cells of RA and osteoarthritis (OA) patients have been shown to exhibit anti-inflammatory properties in vitro. ${ }^{9}$ However, important cofactors and inducers of this catecholamine-producing enzyme have never been studied and the role of $\mathrm{TH}^{+}$cells in vivo is not known yet.

$\mathrm{TH}$ is regulated by the phosphorylation status of subunits, ${ }^{13}{ }^{14}$ environmental $\mathrm{pH}$ value, ${ }^{15}$ specific stimulatory cofactors such as tetrahydrobiopterin $\left(\mathrm{BH}_{4}\right)$ and bivalent iron $\left(\mathrm{Fe}^{2+}\right),{ }^{13} 16$ product feedback inhibition, and proteasomal degradation. ${ }^{17}$ In addition, hypoxia was shown to enhance $\mathrm{TH}$ gene expression, TH mRNA stability and TH activity by increasing phosphorylation of $\mathrm{TH} .{ }^{18}{ }^{19}$ Inflammation is accompanied by hypoxia; ${ }^{20}$ hypoxia plays an important role in disease progression in RA. ${ }^{21-23}$ Under these considerations, we expected that hypoxia influences expression and activity of $\mathrm{TH}$ in chronically inflamed tissue. This might result in enhanced catecholamine synthesis of $\mathrm{TH}^{+}$cells, which in turn might affect inflammatory cytokine production in vitro.

In order to study $\mathrm{TH}^{+}$cell effects in vivo, treatment of arthritic animals with $\mathrm{TH}^{+}$cells is mandatory. To our knowledge, $\mathrm{TH}^{+}$cells do not express suitable surface markers to separate these cells by respective sorting techniques demanding a different strategy. Human $\mathrm{TH}^{+}$cells expressing specific markers such as TH, $\beta$-III-tubuline (neuronal intracellular scaffold protein), vesicular monoamine transporter 2 (VMAT-2) and nuclear receptor related 1 (Nurr1) protein have been generated on the basis of mesenchymal stem cells (MSCs). ${ }^{24} 25$ These cells are $\mathrm{TH}^{+}$neuronal precursor cells (called $\mathrm{TH}^{+}$neuronal cells). However, no similar differentiation experiments have been performed to generate $\mathrm{TH}^{+}$neuronal cells in rodents, and these cells have not been used in experimental arthritis in mice or in other disease models.

The aim of these studies was to investigate hypoxia-induced effects on $\mathrm{TH}$ expression, catecholamine release and inflammatory cytokine release in $\mathrm{RA} / \mathrm{OA}$ human synovial cells in vitro. $\mathrm{TH}$ cofactors $\left(\mathrm{BH}_{4}\right.$ and $\left.\mathrm{Fe}^{2+}\right)$ were used to amplify the function of $\mathrm{TH}$, and cytokine release was
To cite: Jenei-Lanzl Z,

Ann Rheum Dis

2015;74:444-451. 
investigated. In addition, $\mathrm{TH}^{+}$neuronal cells were generated from murine MSCs in order to perform adoptive transfer experiments during collagen type II-induced arthritis (CIA) in mice. Effects of adoptively transferred $\mathrm{TH}^{+}$neuronal cells were studied under treatment with 6-hydroxydopamine (6OHDA) to kill $\mathrm{TH}^{+}$cells.

\section{MATERIALS AND METHODS}

Human samples were collected with informed consent of the involved individuals, and mouse experiments were performed in accordance with local institutional and governmental regulations for animal use. The project was approved by the Ethics Committee of the University of Regensburg. A more complete and detailed description of the methods is included in online supplementary SI materials and methods.

\section{Human synovial cell culture}

Human mixed synoviocytes were incubated under hypoxic and normoxic conditions for $24 \mathrm{~h}$ with specific TH cofactors $\mathrm{BH}_{4}$ (6R-5,6,7,8-tetrahydrobiopterin dihydrochloride), bivalent iron $\left(\mathrm{Fe}^{2+}\right.$ sulfate heptahydrate), $\alpha$-methyl-para-tyrosine ( $\alpha \mathrm{mpT}$; a competitive TH blocker), monoaminooxidase (MAO) inhibitor bifemelane hydrochloric acid (HCL) and catechol-Omethyltransferase (COMT) inhibitor OR-486 at indicated concentrations. Supernatant was collected and concentrations of interleukin (IL)-6, IL-8 and tumour necrosis factor (TNF) were determined by ELISA or Luminex technology. For catecholamine determination high pressure liquid chromatography (HPLC) was performed. Expression of TH was analysed by immunocytochemistry in chamber slides and via western blotting.

\section{Mouse experiments}

Murine bone marrow-derived stem cells (MSCs) were isolated from bone chips of DBA/1J mice, expanded and characterised. Catecholaminergic induction was initiated with a specific catecholaminergic cocktail. Generated $\mathrm{TH}^{+}$neuronal cell characterisation was performed by light and immunofluorescence microscopy, western blotting, HPLC and using 6OHDA, which destroys $\mathrm{TH}^{+}$cells specifically. For adoptive transfer, $\mathrm{TH}^{+}$neuronal cells were intravenously injected into the tail vein of DBA/ 1J mice with collagen-induced arthritis when an arthritis score of 10 was reached. Clinical arthritis score was determined until day 55 after immunisation. In another experiment, catecholaminergic cells were labelled using the red fluorescent PKH26 in order to characterise localisation of cells in the body of mice. Sections of organs and paws were screened for labelled cells by fluorescence microscopy. In a further set of experiments, beginning on day 10 after $\mathrm{TH}^{+}$neuronal cell adoptive transfer, 6OHDA was injected intraperitoneally on three consecutive days and clinical arthritis score was determined in order to follow-up the role of injected $\mathrm{TH}^{+}$neuronal cells.

\section{RESULTS}

\section{Hypoxia induces TH in mixed synovial cells}

Hypoxic conditions compared with normoxia induced $\mathrm{TH}$ protein expression in both OA and RA cell cultures (figure 1A). This observation was confirmed by western blotting because
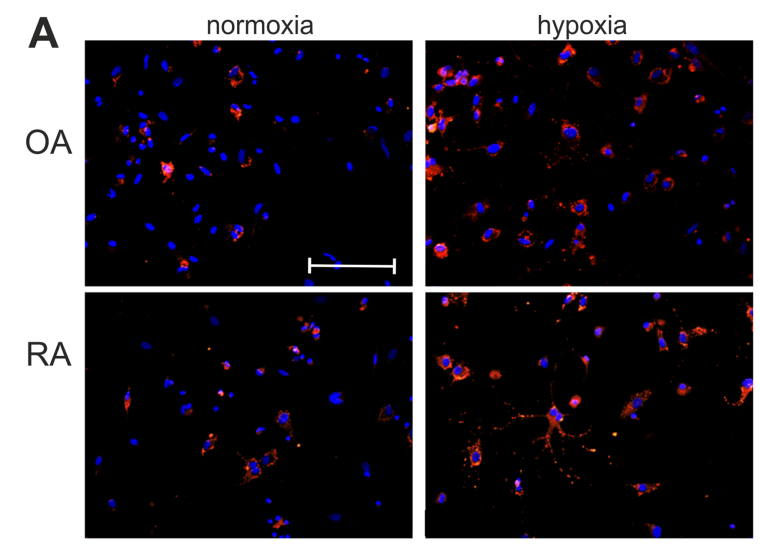

C

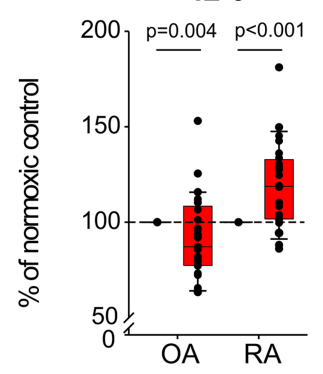

IL-8

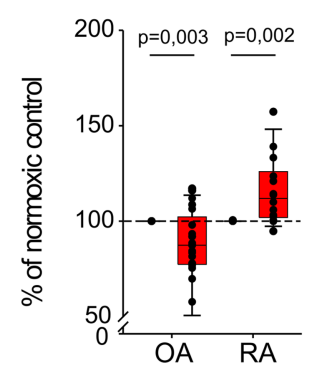

B

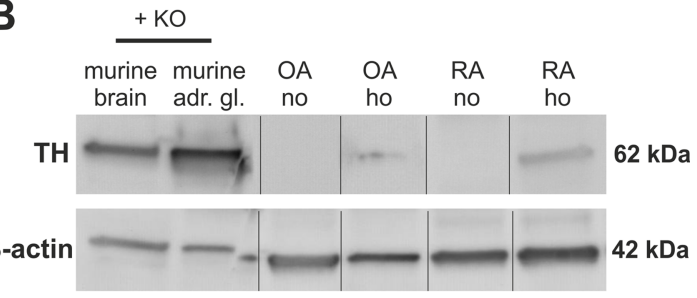

Figure 1 Effects of hypoxia on tyrosine hydroxylase $(\mathrm{TH})$ expression and cytokine release in synovial cells of patients with osteoarthritis (OA) and rheumatoid arthritis (RA). (A) Immunofluorescent detection of TH-positive synovial cells after $24 \mathrm{~h}$ of normoxic or hypoxic incubation (Bar $100 \mu \mathrm{m}$ ). (B) Western blot analysis of TH expression in synovial cells from OA and RA patients after $24 \mathrm{~h}$ of normoxic or hypoxic incubation (see also supplementary figure 2). (C) Quantification of released cytokines in supernatants of synovial cells from OA and RA patients after $24 \mathrm{~h}$ of normoxic or hypoxic incubation $(n=21-44)$. Data are presented as box plots, where the boxes represent the 25th to 75th percentiles, the lines within the boxes represent the median, and the lines outside the boxes represent the 10th and 90th percentiles. The red boxes represent hypoxic conditions. Values are demonstrated in per cent of the normoxic control (untreated normoxic control=100\%, broken line). adr. gl, adrenal gland; no, normoxia; ho, hypoxia. 


\section{Basic and translational research}

after $24 \mathrm{~h}$ under hypoxic conditions, total $\mathrm{TH}$ was increased compared with normoxic conditions (figure 1B).

\section{Hypoxia-dependent TH induction influences inflammatory cytokine release}

Incubation of mixed synovial cells under hypoxic conditions resulted in an altered inflammatory cytokine release pattern compared with normoxic incubation (figure 1C). In OA synovial cells, each analysed cytokine (IL-6, IL-8 and TNF) was significantly reduced by hypoxia (figure $1 \mathrm{C}$ ). In contrast, in RA synovial cells, IL- 6 and IL- 8 increased significantly after hypoxic incubation, whereas TNF was significantly reduced similar to OA synovial cells (figure 1C).

Involvement of $\mathrm{TH}$ in these observed effects was tested using the competitive TH inhibitor $\alpha \mathrm{mpT}$, which was able to reverse hypoxia-mediated TNF reduction significantly at $1 \mu \mathrm{g} / \mathrm{mL}$ in both OA and RA synovial cell cultures (figure 2A). In OA synovial cells under normoxic conditions, $\alpha \mathrm{mpT}$ at $0.1 \mu \mathrm{g} / \mathrm{mL}$ also increased TNF (figure 2A). In the case of RA cells, the $1 \mu \mathrm{g} / \mathrm{mL}$ concentration of $\alpha \mathrm{mpT}$ was able to significantly increase TNF under normoxic conditions (figure 2A). The dose-response curve has a bell-shaped form, which can be due to toxic/unspecific effects at $10 \mu \mathrm{g} / \mathrm{mL}$ (figure $2 \mathrm{~A}$ ).

\section{Specific TH cofactors enhance hypoxia-mediated effects on cytokines}

In order to further increase $\mathrm{TH}$ activity, specific $\mathrm{TH}$ cofactors such as $\mathrm{BH}_{4}$ and $\mathrm{Fe}^{2+}$ were added. In combination $\left(\mathrm{BH}_{4} 0.1 \mathrm{mM}\right.$ and $\mathrm{Fe}^{2+} 10 \mathrm{nM}$ ), these cofactors enhanced hypoxia-mediated effects on IL- 6 and TNF in both OA and RA synovial cell cultures (figure 2B): In OA cell culture, IL-6 decreased from $85 \%$ of the normoxic control to $60 \%$ and TNF declined from $90 \%$ to $80 \%$. In RA synovial cells, IL- 6 rose from $110 \%$ of the normoxic control to $140 \%$ and TNF decreased from $85 \%$ to $75 \%$ (figure 2B). In OA synovial cells, $0.1 \mathrm{mM} \mathrm{BH}_{4}$ and $10 \mathrm{nM} \mathrm{Fe}^{2+}$ exhibited inhibitory effects on IL-6 also under normoxia (figure 2B). All these described effects caused by $\mathrm{BH}_{4}$ and $\mathrm{Fe}^{2+}$ were reversed by the competitive $\mathrm{TH}$ inhibitor $\alpha \mathrm{mpT}$ (figure $2 \mathrm{~B}$ ).
A

OA
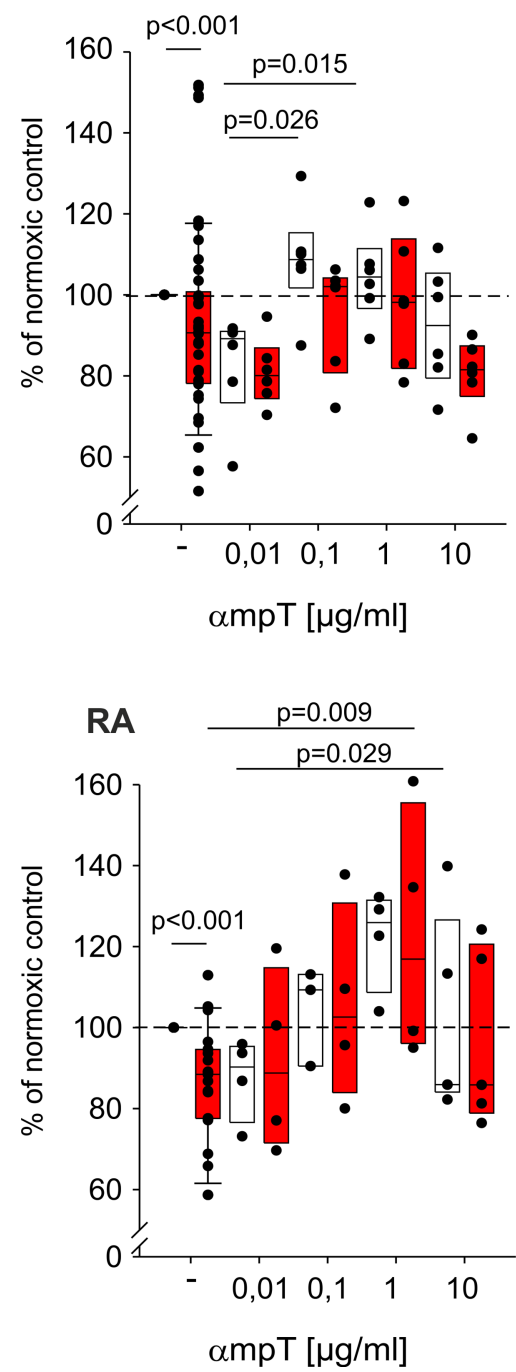

B
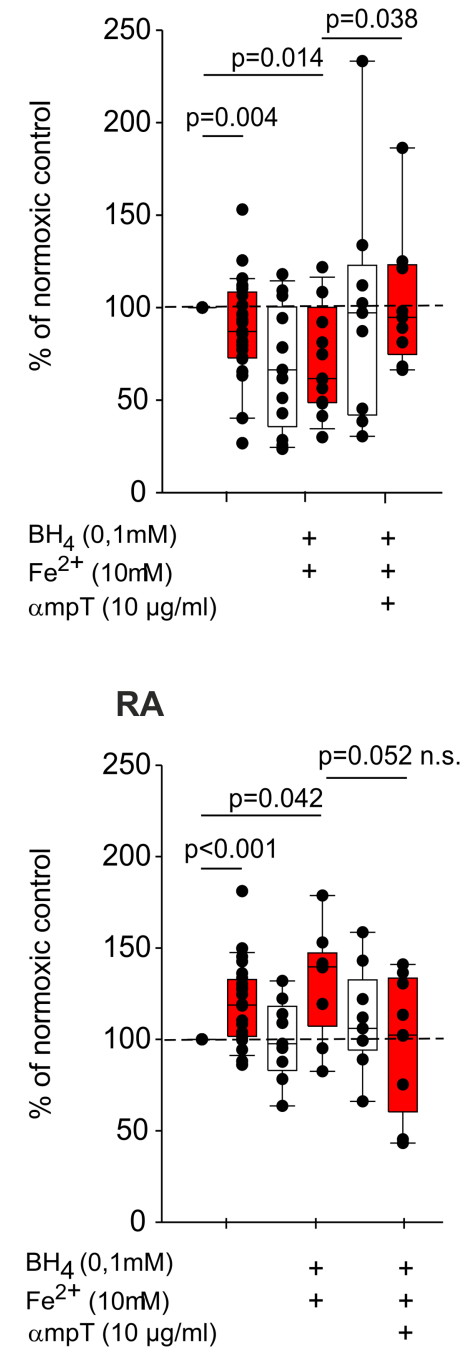

TNF
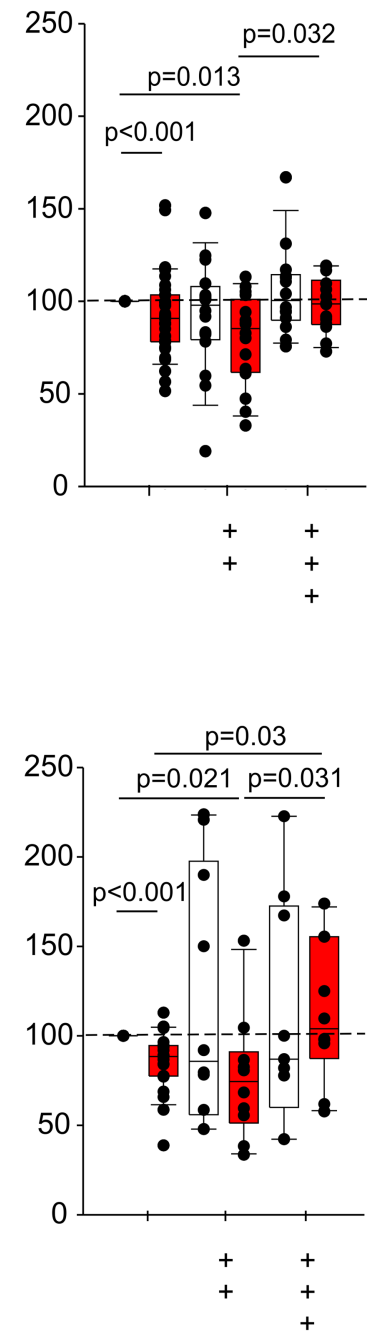

Figure 2 Modulation of inflammatory cytokine release of synovial cells by tyrosine hydroxylase (TH) cofactors and a TH inhibitor in synovial cells of patients with osteoarthritis (OA) and rheumatoid arthritis (RA). (A) Reversion of hypoxia-mediated TNF inhibition by the competitive TH inhibitor $\alpha$-methyl-para-tyrosine $(\alpha \mathrm{mpT}, \mathrm{n}=6-44)$. (B) Influence of the two TH cofactors tetrahydrobiopterin $\left(\mathrm{BH}_{4}\right)$ and $\mathrm{Fe}^{2+}$ on release of IL-6 and TNF with/ without $\alpha \mathrm{mpT}(\mathrm{n}=9-10)$. Box plots are explained in legend to figure 1. The red (white) boxes show hypoxic (normoxic) conditions. Data points are presented as per cent of the untreated normoxic control group (untreated normoxic control $=100 \%$, broken line). 


\section{Catecholamine biosynthesis in synovial cell culture}

The effect of catecholamines on TNF release demonstrated above might be stronger in the presence of inhibitors of catecholamine-degrading enzymes (MAO and COMT inhibitors). Under hypoxic conditions, MAO and COMT inhibitors enhanced TNF inhibition significantly in both OA and RA synovial cell culture (figure 3A). The same MAO and COMT inhibitor-dependent effect was observed under normoxic conditions (figure 3A).

A good indication of TH activity is the release of catecholamines into the supernatant. Using both OA and RA cells, concentration of catecholamines in cell supernatants incubated under normoxia was at the detection limit. Under hypoxia, higher catecholamine levels were measured (approximately $10^{-9}-10^{-8} \mathrm{M}$, figure $3 \mathrm{~B}$ ).

The coincubation with MAO and COMT inhibitors resulted in catecholamine accumulation. After $24 \mathrm{~h}$ of hypoxic incubation, higher catecholamine concentrations were detected compared with normoxia or to supernatants without MAO and COMT inhibitors in both OA and RA synovial cell cultures (figure 3B).

\section{Catecholaminergic differentiation of murine MSCs}

Until now, we were not able to demonstrate a direct antiinflammatory effect of $\mathrm{TH}^{+}$cells in experimental arthritis because $\mathrm{TH}^{+}$cells cannot be separated by magnetic or fluorescent sorting techniques. Thus, we decided to generate $\mathrm{TH}$ expressing cells from MSCs in mice to treat animals with CIA.

Cells from murine bone chips that proliferated until passage 4 exhibited fibroblast-like morphology (figure 4A,B,F) and a MSC-specific surface marker pattern (see online supplementary figure S1). In addition, these cells were able to differentiate into adipocytes (figure 4C), osteocytes (figure 4D) and chondrocytes (figure 4E) in cell linage-specific differentiation media.

After 12 days of catecholaminergic differentiation, induced $\mathrm{TH}^{+}$neuronal cells were compared with MSCs morphologically and immunocytologically. In contrast to MSCs, induced $\mathrm{TH}^{+}$ neuronal cells expressed neuronal precursors and showed neuron-like morphology (figure 4F). Differentiated $\mathrm{TH}^{+}$neuronal cells formed cell-connected rosette-like patterns, which is characteristic for neurogenic differentiation. ${ }^{26}$ While MSCs were definitely negative for catecholaminergic markers such as
A

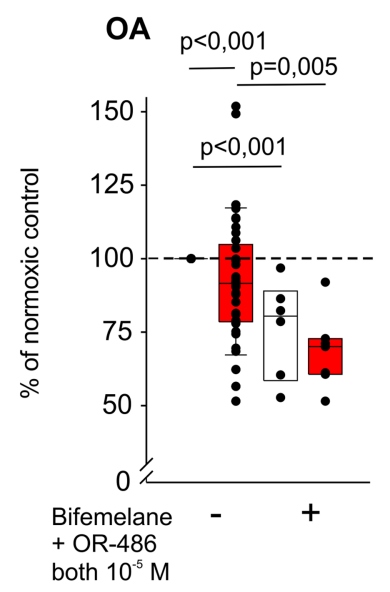

B

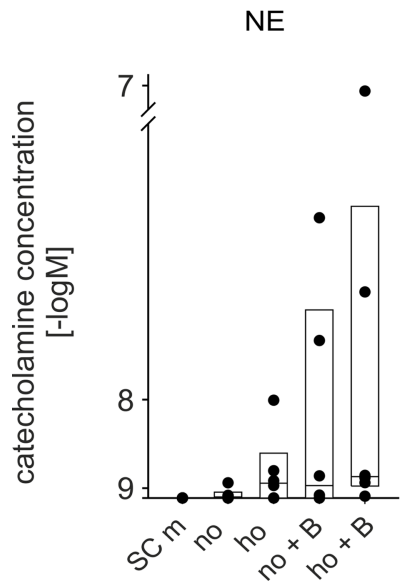

OA

DA

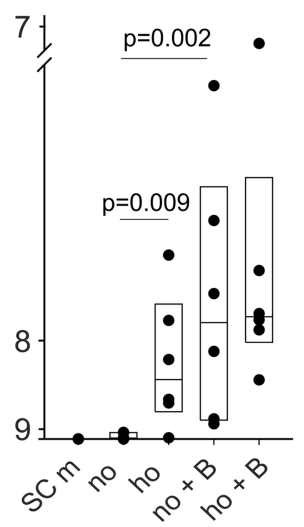

TNF

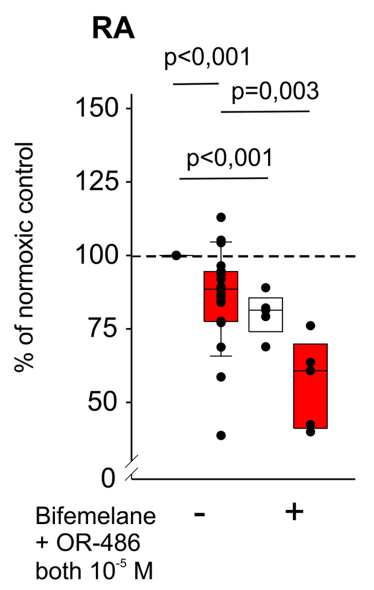

RA

NE

DA

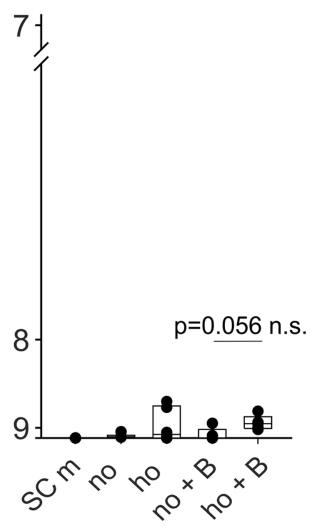

Figure 3 Catecholamine and TNF release of synovial cell cultures of patients with osteoarthritis (OA) and rheumatoid arthritis (RA). Box plots are explained in legend to figure 1. (A) Enhanced TNF inhibition due to catecholamine accumulation caused by treatment of synovial cells with MAO and COMT blockers (each $10^{-5} \mathrm{M} ; \mathrm{n}=6-44$ ). The red (white) boxes in (A) show hypoxic (normoxic) conditions. Values in (A) are demonstrated in \% of the normoxic control (untreated normoxic control: 100\%, broken line). (B) Catecholamine levels (NE, norepinephrine; DA, dopamine) in synoviocyte supernatants after $24 \mathrm{~h}$ of normoxic or hypoxic incubation $(\mathrm{n}=6-7)$. SCm, medium without cells; no, normoxia; ho, hypoxia; no+B, normoxia plus blockers of monoamino oxidase (MAO, bifemelane $10^{-5} \mathrm{M}$ ) and catechol-0-methyl-transferase (COMT, OR-486 10 $\left.{ }^{-5} \mathrm{M}\right)$; ho+B, hypoxia plus MAO and COMT blockers. 
A

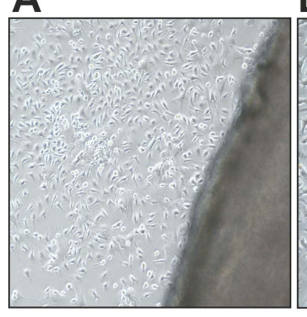

B

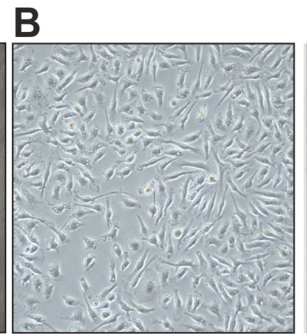

C

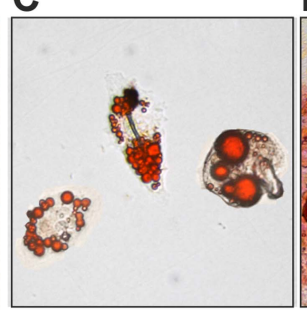

F
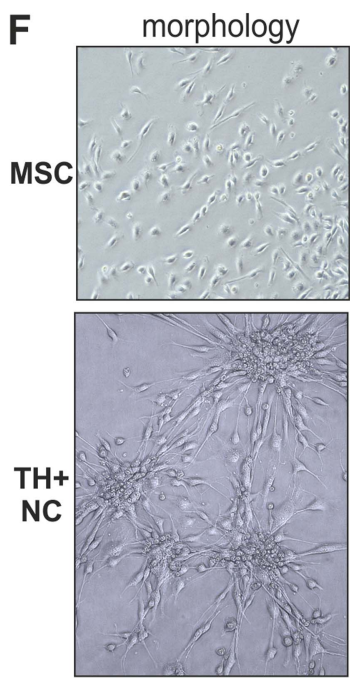

$\beta$ III-tubulin
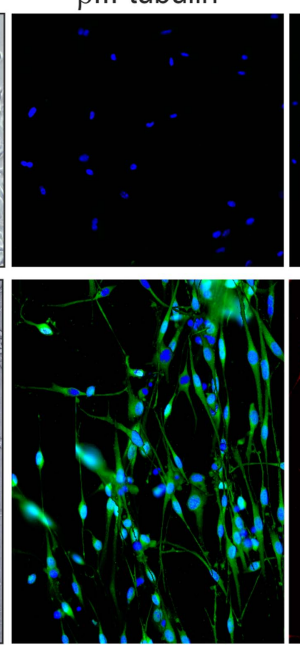

$\mathrm{TH}$
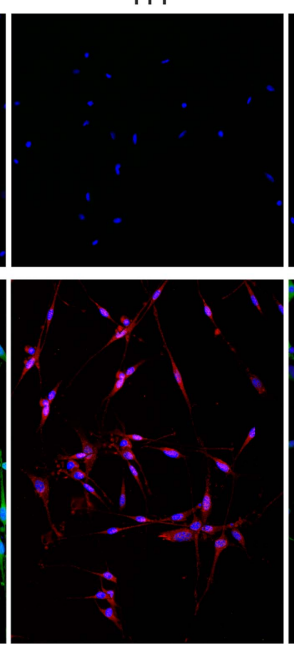

D

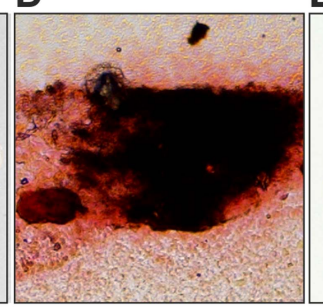

E

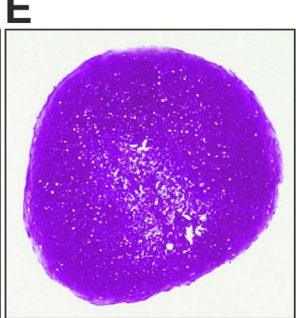

VMAT-2
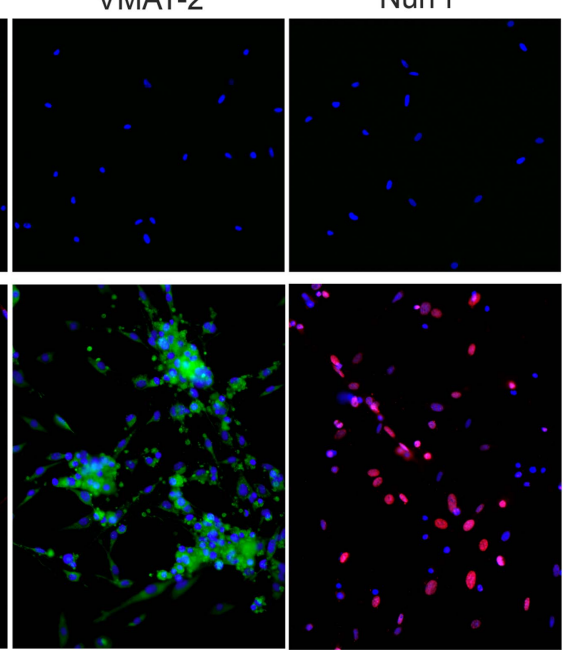

Figure 4 Characterisation of murine mesenchymal stem cell (mMSCs)-derived tyrosine hydroxylase-positive $\left(\mathrm{TH}^{+}\right)$neuronal cells. $(\mathrm{A}$ and $\mathrm{B}) \mathrm{mMSCs}$ migrating from bone chips (A, magnification $100 x$ ) and proliferating in plastic flasks (B, magnification 200x). (C-E) Multilineage differentiation of mMSCs to adipocytes (C, magnification $400 x$ ), osteoblasts $(D$, magnification $100 x$ ) and chondrocytes ( $E$, magnification $40 x)$. ( $F$ ) Characterisation of $\mathrm{TH}^{+}$neuronal cells compared with mMSCs using phase contrast microscopy (200x), and antibodies to $\beta$ III-tubulin, TH, vesicular monoamine transporter 2 (VMAT-2), nuclear receptor related 1 (Nurr1). Magnifications: $200 \times$. $\mathrm{TH}^{+} \mathrm{NC}, \mathrm{TH}^{+}$neuronal cells.

BIII-tubulin, TH, VMAT-2 and Nurr1 (figure 4F), induced $\mathrm{TH}^{+}$ neuronal cells clearly expressed all these catecholaminergic markers (figure 4F).

In MSC culture supernatants, catecholamine concentrations were below the detection limit (approximately $10^{-9} \mathrm{M}$, figure $5 \mathrm{~A}$ ). At day 7 of catecholaminergic differentiation, that is, shortly before brain-derived neurotrophic factor (BDNF) supplementation, cells secreted catecholamines leading to concentrations of up to $10^{-8} \mathrm{M}$ (figure 5A). On day 12, catecholamine concentrations increased to $10^{-7} \mathrm{M}$ (figure $5 \mathrm{~A}$ ). While both norepinephrine and dopamine were measured (figure 5A), epinephrine was not measurable.

In order to study whether 6OHDA can deplete induced $\mathrm{TH}^{+}$ neuronal cells in vitro, 6OHDA was incubated together with these cells. After $24 \mathrm{~h} 6 \mathrm{OHDA}$ treatment, no vital induced $\mathrm{TH}^{+}$ neuronal cells were detected in chamber slides (figure $5 \mathrm{~B}$, red colour $=$ dead cells). In contrast, almost $100 \%$ of MSCs survived 6OHDA treatment (figure 5B, green colour=vital cells).

High $\mathrm{TH}$ expression of induced $\mathrm{TH}^{+}$neuronal cells was confirmed by western blotting (figure 5C). After 12 days of catecholaminergic differentiation, induced $\mathrm{TH}^{+}$neuronal cells showed high $\mathrm{TH}$ expression, whereas $\mathrm{TH}$ was not detected in MSC (figure 5C). $\beta$-Actin expression was not affected during catecholaminergic differentiation (figure $5 \mathrm{C}$ ).

\section{Cell therapy with induced $\mathrm{TH}^{+}$neuronal cells in experimental arthritis}

To investigate the influence of in vitro-induced $\mathrm{TH}^{+}$neuronal cells, these cells were adoptively transferred to animals with CIA. MSC- and PBS-treated mice were used as controls.
We studied tissue distribution of injected PKH26-labelled $\mathrm{TH}^{+}$neuronal cells. After $24 \mathrm{~h}$, induced $\mathrm{TH}^{+}$neuronal cells were detected in paw joints, lymph nodes, spleen and adrenal gland (figure 6A). No labelled $\mathrm{TH}^{+}$neuronal cells were found in brain, lung, heart, digestive organs or in kidneys.

CIA appeared on day 19-21 after immunisation, and score 10 was reached on day 22-25 after immunisation (figure 6B). Clinical arthritis scores of control mice showed a characteristic progression with strong increase between day 22 and 38 after immunisation and a maximum mean score of 25 score points on day 35-38 (figure 6B). In contrast, mice treated with 1 million induced $\mathrm{TH}^{+}$neuronal cells developed a significantly milder arthritis (figure $6 \mathrm{~B}, \mathrm{p}=0.025$ for comparison vs controls using general lineal model). Treatment effects of induced $\mathrm{TH}^{+}$neuronal cells were observed from day 10 after adoptive transfer and a marked difference versus control animals remained until the end of observation (day 30 after one-shot cell treatment). MSC treatment also resulted in a milder but not significantly ameliorated arthritis (see online supplementary figure S3A, p=0.222 for comparison vs controls using general linear model).

The H\&E staining of cryo-sections showed a higher number of cell nuclei in synovial tissue in phosphate-buffered saline (PBS) injected control paws. In contrast, in sections of MSC- or $\mathrm{TH}^{+}$neuronal cell-treated paws cell infiltration was less pronounced (see online supplementary figure S4).

Since 6OHDA treatment induced a strong pro-inflammatory increase in late CIA ${ }^{8}$ and since 6OHDA can deplete induced $\mathrm{TH}^{+}$neuronal cells in vitro (figure $5 \mathrm{~B}$ ), we hypothesised that injection of 6OHDA increases arthritis severity in animals 

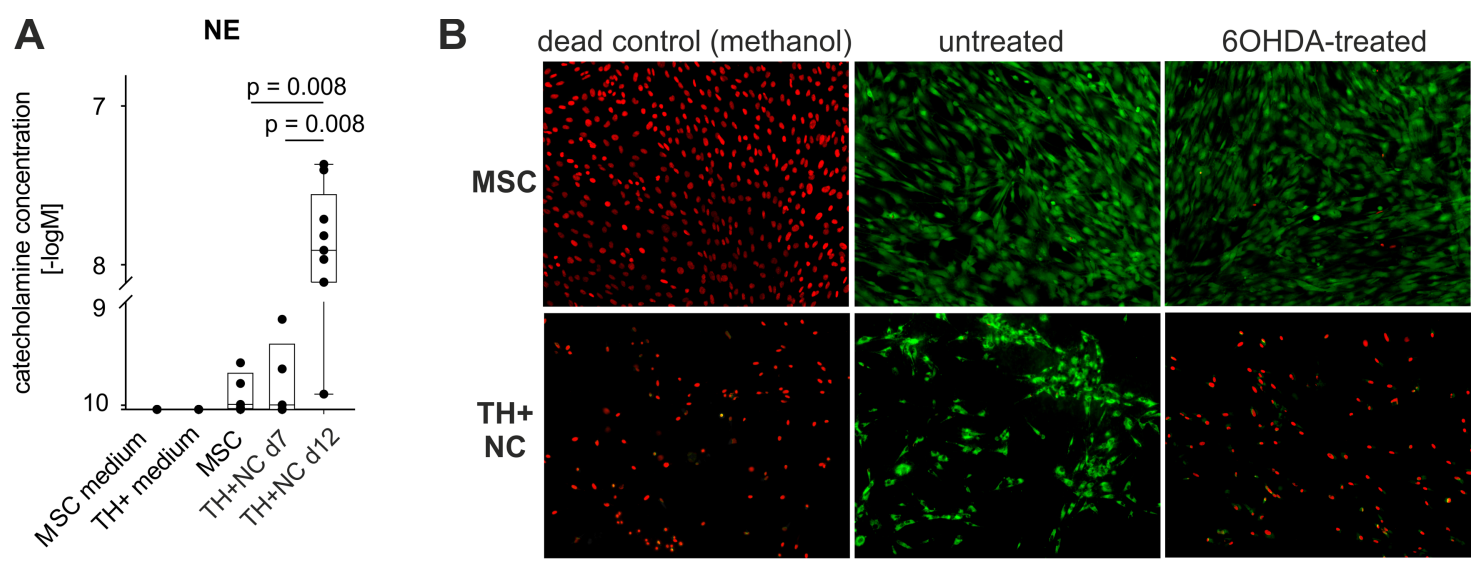

DA
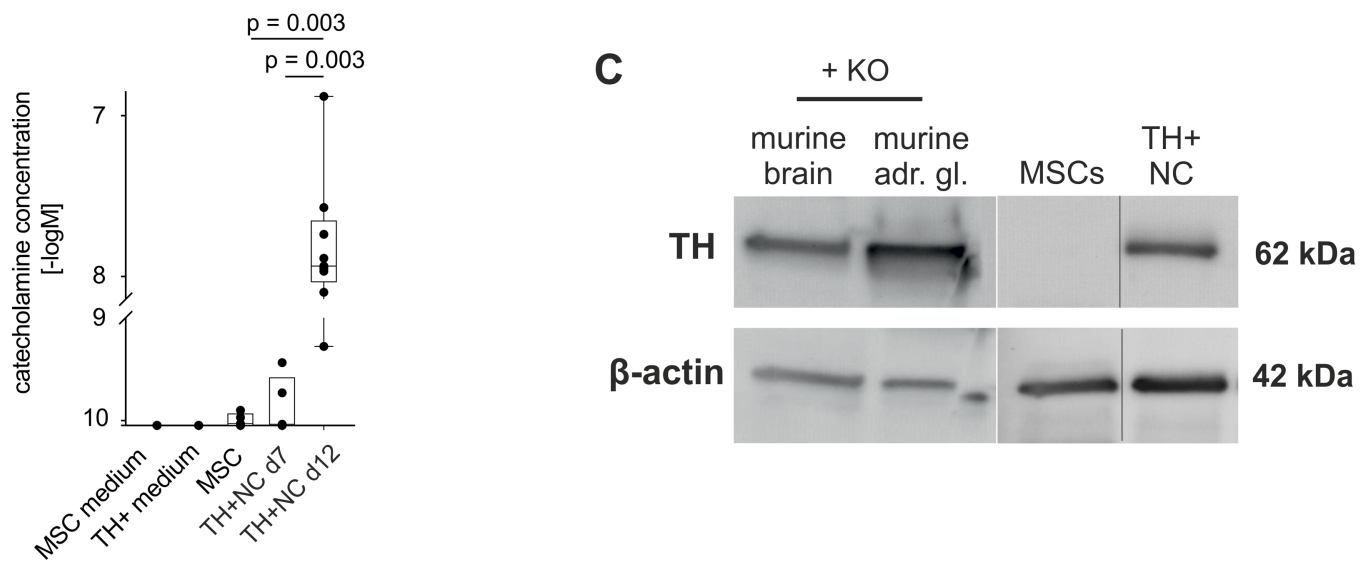

Figure 5 Catecholamine secretion and tyrosine hydroxylase $(\mathrm{TH})$ expression in murine mesenchymal stem cell (mMSCs)-derived $\mathrm{TH}^{+}$neuronal cells. (A) Secretion of catecholamines (NE, norepinephrine; DA, dopamine) in media without cells (mMSC medium, TH medium) and in supernatants of mMSCs and $\mathrm{TH}^{+}$neuronal cells $(\mathrm{n}=8-10)$. Box plots are explained in legend to figure 1. (B) Targeted killing of $\mathrm{TH}^{+}$neuronal cells by 6-hydroxydopamine (6OHDA) and detection of live/dead cells after 60HDA treatment. (C) Western blot analysis of expression of $\mathrm{TH}^{\text {in }} \mathrm{TH}^{+}$neuronal cells compared with mMSCs. $\mathrm{TH}^{+} \mathrm{NC}, \mathrm{TH}^{+}$neuronal cells.

treated with $\mathrm{TH}^{+}$neuronal cells. Indeed, intraperitoneal injection of 6OHDA 10 days after adoptive transfer resulted in a short initial fall followed by a steady increase of arthritis scores until day 30 after cell treatment (figure 6C). This reached the level of arthritic animals without cell treatment (figure 6C). No similar effects of 6OHDA were observed in control or MSC-treated animals (see online supplementary figure S3B, $\mathrm{p}=0.966$ using general linear model; online supplementary figure S3C, $\mathrm{p}=0.069$ using general linear model).

\section{DISCUSSION}

For three decades, anti-inflammatory effects of catecholamines such as norepinephrine are known when these neurotransmitters operate via $\beta$-adrenoceptors (reviewed in ${ }^{27}$ ). Thus, the loss of sympathetic nerve fibres in inflamed tissue was interpreted as a pro-inflammatory event. ${ }^{2} 728$ Importantly, concomitant to the loss of sympathetic nerve fibres there appear newly formed cells that express $\mathrm{TH}$, which we called $\mathrm{TH}^{+}$cells or catecholaminergic cells, ${ }^{9}{ }^{10}$ but their role is unclear. While some authors hypothesised that these cells have pro-inflammatory activities, ${ }^{29} \mathrm{TH}^{+}$cells might have anti-inflammatory capacities when neurotransmitter concentrations are high enough for $\beta$-adrenergic signalling. ${ }^{9}$

It was the starting point of the present work to find mechanisms that can increase $\mathrm{TH}$ protein expression and function in inflammatory cells in order to increase local catecholamine levels. An important factor to increase $\mathrm{TH}$ expression is hypoxia. ${ }^{18} 193031$ In the present study, we demonstrated that TH expression increased when mixed synovial cells of OA and RA patients were incubated under hypoxic conditions. This confirms the work in other cell types. ${ }^{30} 31$ Hypoxia reduced TNF levels in OA and RA synovial cells, downregulated IL-6/IL-8 in OA, but upregulated IL-6/IL-8 in RA. While several studies demonstrated differential results of hypoxia on various cytokines, ${ }^{32}{ }^{33}$ this is similarly ambiguous in primary synovial cells of RA and OA in our study (which are mainly macrophages and fibroblasts). At the moment, we have no conclusions why RA and OA cells behave in such a different way.

In order to demonstrate the specific hypoxia effect of $\mathrm{TH}$ on cytokine secretion, we blocked $\mathrm{TH}$ by the highly competitive antagonist $\alpha \mathrm{mpT}$. These hypoxia-mediated effects were enhanced when we used specific TH cofactors $\mathrm{BH}_{4}$ and $\mathrm{Fe}^{2+}$, which are known to optimise TH activity. TNF inhibition in OA/RA synovial cells by hypoxia was abrogated by $\alpha \mathrm{mpT}$ demonstrating specific effects via this catecholaminergic key enzyme. Similarly, hypoxia-induced effects on IL-6 secretion in OA/RA synovial cells were augmented with $\mathrm{BH}_{4}$ and $\mathrm{Fe}^{2+}$ and, again, these changes were eliminated by $\alpha \mathrm{mpT}$. These experiments support hypoxia-induced effects on cytokines via an increase of TH.

Another important aspect in this research is determination of environmental catecholamines in the proximity of $\mathrm{TH}^{+}$cells because high levels of norepinephrine are desired ( $\beta$-adrenergic anti-inflammatory effects). In earlier studies, we demonstrated 

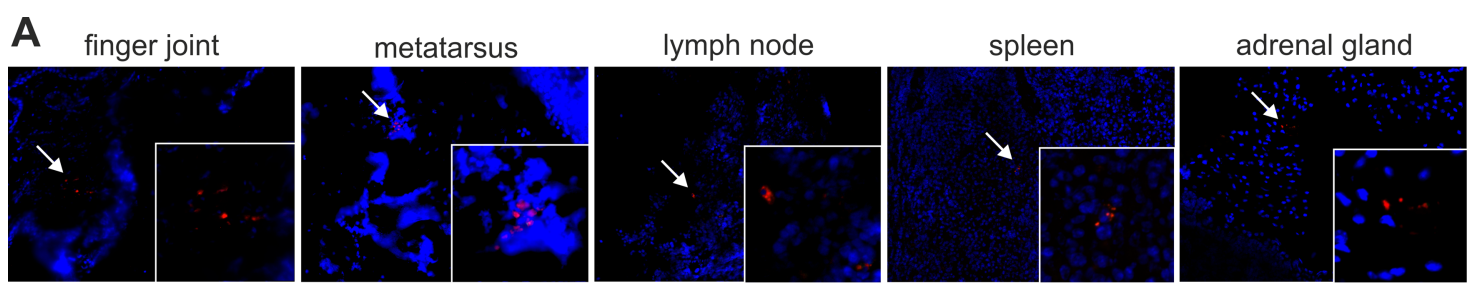

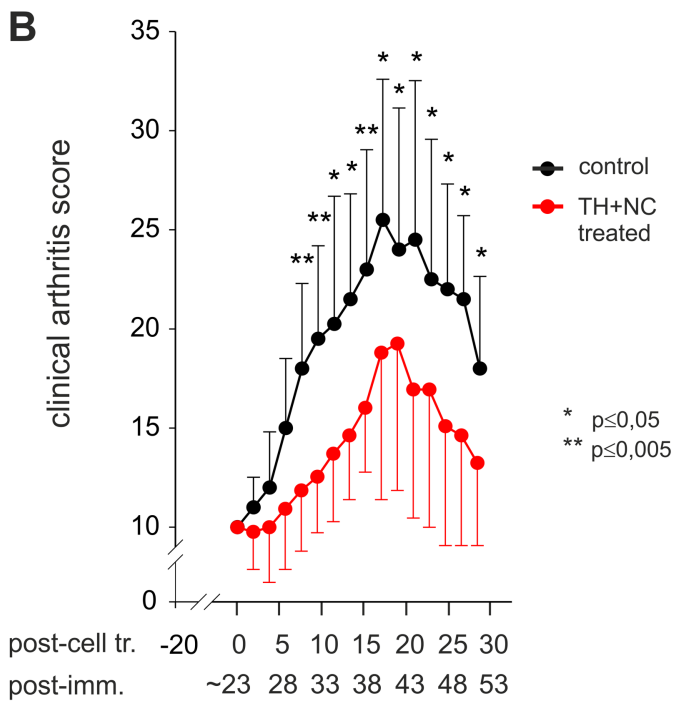

$\mathrm{t}$ [days]

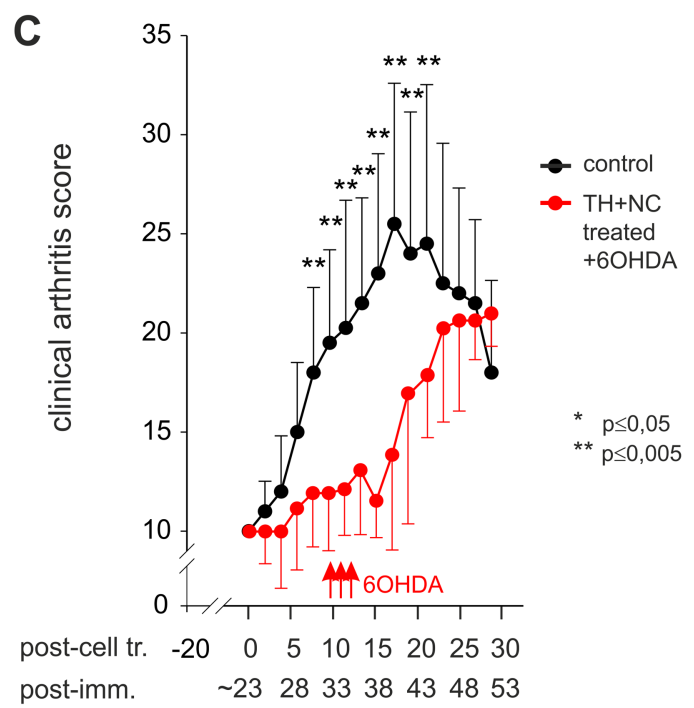

$\mathrm{t}$ [days]

Figure 6 Generated tyrosine hydroxylase-positive $\left(\mathrm{TH}^{+}\right)$neuronal cells in experimental arthritis and organ distribution. (A) Detection of PKH26 prelabelled $\mathrm{TH}^{+}$neuronal cells in paw joints, lymph nodes, spleen and adrenal gland of arthritic mice after intravenous injection. (B) Anti-inflammatory effects of $\mathrm{TH}^{+}$neuronal cells on clinical score of experimental arthritis after intravenous injection compared with control arthritic mice $(n=14)$.

(C) Reversion of anti-inflammatory effects of $\mathrm{TH}^{+}$neuronal cells by intraperitoneal treatment of arthritic mice with 6-hydroxydopamine (6OHDA) $(\mathrm{n}=14)$. post-cell tr, days after adoptive transfer of $\mathrm{TH}^{+}$neuronal cells; post-immun, days after immunisation.

presence of catecholamines in cultures of synovial $\mathrm{TH}^{+}$cells $(5.9 \mathrm{pmol} / \mathrm{L}, 0.5 \text { and } 1.0 \mathrm{nmol} / \mathrm{L})^{9}{ }^{11}$ and in perfusion culture of synovial tissue $(0.5-0.8 \mathrm{nmol} / \mathrm{L}){ }^{11}$ In order to improve the detection of catecholamines, inhibitors of catecholamine degrading enzymes, $\mathrm{MAO}$ and COMT, were used (in addition to $\mathrm{BH}_{4}$ and $\mathrm{Fe}^{2+}$ treatment). Under these conditions, norepinephrine levels rose to $10-100 \mathrm{nmol} / \mathrm{L}\left(10^{-7} \mathrm{~mol} / \mathrm{L}\right)$. This indicates that environmental conditions can exist, which lead to high neurotransmitter levels relevant for $\beta$-adrenergic signalling. Importantly, by administration of MAO plus COMT blockers, inhibitory effects of hypoxia on TNF secretion in OA and RA cells was markedly increased, which indicates a specific catecholaminergic effect.

Results in vitro persuaded us to test effects of $\mathrm{TH}^{+}$cells in vivo in experimental arthritis in mice. Since these cells cannot be separated by magnetic or fluorescent sorting techniques (no specific surface molecule), $\mathrm{TH}^{+}$cells were generated using murine MSCs as described previously for human MSCs. ${ }^{24}$ We called these cells $\mathrm{TH}^{+}$neuronal cells.

Injected $\mathrm{TH}^{+}$neuronal cells were found in paws but also in abdominal organs (lymph nodes, spleen, adrenal glands). The presence of $\mathrm{TH}^{+}$neuronal cells in the joints $24 \mathrm{~h}$ after cell injection demonstrates clearly that $\mathrm{TH}^{+}$neuronal cells survive in vivo, migrate and exert anti-inflammatory effects. The migration of induced $\mathrm{TH}^{+}$neuronal cells into lymph nodes and spleen suggests an additional anti-inflammatory immune response contributing to possible favourable local effects.
Importantly, cellular therapy with $\mathrm{TH}^{+}$neuronal cells led to a significant reduction of inflammation, which remained stable until the end of the observation period. One single injection of $\mathrm{TH}^{+}$neuronal cells was sufficient to maintain anti-inflammatory effects for a long period of time. Similarly, MSC-treated mice developed milder arthritis confirming earlier studies. ${ }^{34}$ However, MSCs act as key regulators of immune tolerance by inducing the generation/activation of Treg cells and not via the key enzyme of catecholamine production since these cells do not express $\mathrm{TH}$. Positive effects of $\mathrm{TH}^{+}$neuronal cells and MSC were confirmed by $\mathrm{H} \& \mathrm{E}$ staining.

In order to show that $\mathrm{TH}^{+}$neuronal cells are responsible for milder arthritis, we depleted $\mathrm{TH}^{+}$neuronal cells by treatment with 6OHDA as demonstrated earlier. ${ }^{10}$ During these experiments, a short decrease of arthritis score was observed during injection of 6OHDA. We hypothesise that this effect is most likely depending on acute catecholamine release from sympathetic nerve fibres and $\mathrm{TH}^{+}$cells after 6OHDA injection, which is termed the initial 6OHDA norepinephrine burst. Such a catecholamine burst is well known after treatment with 6OHDA (fluffy coat, tachycardia, high activity). However, after this burst period, arthritis symptoms became significantly worse. These experiments confirm earlier experiments of our group in which injection of 6OHDA increased arthritis score in the late phase of CIA (approximately day 55). ${ }^{8}$ It is important to mention that control animals and MSC-treated animals receiving 6OHDA did not show worsening. In earlier experiments, we demonstrated 
that 6OHDA ameliorates CIA when given before or until day 18 after immunisation, while CIA is aggravated when 6OHDA is given after day $45 .^{8} 35$ However, administration of 6OHDA between day 18 and 45 had no effect (we called this interval transition phase). ${ }^{35}$ Since we injected $\mathrm{TH}^{+}$neuronal cells in this transition phase and since we observed worsening effects of 6OHDA in the transition phase, it is most likely that 6OHDA effects are specific through elimination of $\mathrm{TH}^{+}$neuronal cells that were given in the transition phase.

In conclusion, this study demonstrated hypoxia-induced upregulation of TH. TH was responsible for inhibition of TNF in $\mathrm{OA}$ and RA synovial cells demonstrating an anti-inflammatory effect of increased TH function. Cellular therapy with $\mathrm{TH}^{+}$ neuronal cells demonstrated a clear anti-inflammatory influence of these cells in experimental arthritis. In future studies, we will target specific receptors (adrenergic and adenosinergic) in order to elucidate underlying molecular mechanisms of hypoxia driven $\mathrm{TH}$-dependent anti-inflammatory phenomena in arthritis. This will help in developing novel cell therapy options for patients with RA.

Acknowledgements The authors thank Elena Underberg and Madlen Melzer for technical support.

Contributors ZJ-L: discussing the concept, generation of data, generating draft figures, drafting parts of the paper, final approval. SC: generation of data, generating draft figures, revising the draft paper, final approval. FK, MF and TL: providing study tools and techniques, revising the draft paper, final approval. RHS: development of the concept, drafting parts of the paper, generating final figures, final approval.

Funding This study was supported by a grant of the Deutsche Forschungsgemeinschaft to RHS and SC (STR 511/34-1 and CA 933/1-1, within Research Unit FOR696) and part of a grant of the Deutsche Forschungsgemeinschaft to MF (FL 297/10-1).

Competing interests None.

Ethics approval Ethics Committee of the University of Regensburg.

Provenance and peer review Not commissioned; externally peer reviewed.

\section{REFERENCES}

1 Bijlsma JW, Masi A, Straub RH, et al. Neuroendocrine immune system involvement in rheumatology. Ann N Y Acad Sci 2006;1069:xviii-xxxiv.

2 Elenkov IJ. Neurohormonal-cytokine interactions: implications for inflammation, common human diseases and well-being. Neurochem Int 2008:52:40-51.

3 Eskandari F, Webster Jl, Sternberg EM. Neural immune pathways and their connection to inflammatory diseases. Arthritis Res Ther 2003;5:251-65.

4 Hench PS, Slowcumb CH, Polley HF, et al. Effect of cortisone and pituitary adrenocorticotropic hormone (ACTH) on rheumatic diseases. J Am Med Assoc 1950;144:1327-35.

5 Levine JD, Clark R, Devor M, et al. Intraneuronal substance P contributes to the severity of experimental arthritis. Science 1984;226:547-9.

6 Bellinger DL, Millar BA, Perez $S$, et al. Sympathetic modulation of immunity: relevance to disease. Cell Immunol 2008;252:27-56.

7 Ebbinghaus M, Gajda M, Boettger MK, et al. The anti-inflammatory effects of sympathectomy in murine antigen-induced arthritis are associated with a reduction of Th1 and Th17 responses. Ann Rheum Dis 2012;71:253-61.

8 Härle P, Mobius D, Carr DJ, et al. An opposing time-dependent immune-modulating effect of the sympathetic nervous system conferred by altering the cytokine profile in the local lymph nodes and spleen of mice with type II collagen-induced arthritis. Arthritis Rheum 2005;52:1305-13.
9 Capellino $S$, Cosentino M, Wolff $C$, et al. Catecholamine-producing cells in the synovial tissue during arthritis: modulation of sympathetic neurotransmitters as new therapeutic target. Ann Rheum Dis 2010;69:1853-60.

10 Capellino S, Weber K, Gelder M, et al. First appearance and location of catecholaminergic cells during experimental arthritis and elimination by chemical sympathectomy. Arthritis Rheum 2012:64:1110-18.

11 Miller LE, Justen HP, Schölmerich J, et al. The loss of sympathetic nerve fibers in the synovial tissue of patients with rheumatoid arthritis is accompanied by increased norepinephrine release from synovial macrophages. FASEB J 2000;14:2097-107.

12 Miller LE, Grifka J, Schölmerich J, et al. Norepinephrine from synovial tyrosine hydroxylase positive cells is a strong indicator of synovial inflammation in rheumatoid arthritis. J Rheumatol 2002;29:427-35.

13 Dunkley PR, Bobrovskaya L, Graham ME, et al. Tyrosine hydroxylase phosphorylation: regulation and consequences. J Neurochem 2004;91:1025-43.

14 Haycock JW. Phosphorylation of tyrosine hydroxylase in situ at serine 8, 19, 31, and 40. J Biol Chem 1990;265:11682-91.

15 Haavik J, Martinez A, Flatmark T. pH-dependent release of catecholamines from tyrosine hydroxylase and the effect of phosphorylation of Ser-40. FEBS Lett 1990;262:363-5.

16 Schmidt TS, Alp NJ. Mechanisms for the role of tetrahydrobiopterin in endothelial function and vascular disease. Clin Sci (Lond) 2007;113:47-63.

17 Nakashima A. Proteasomal degradation of tyrosine hydroxylase and neurodegeneration. J Neurochem 2012;120:199-201.

18 Kumar GK, Kim DK, Lee MS, et al. Activation of tyrosine hydroxylase by intermittent hypoxia: involvement of serine phosphorylation. J Appl Physiol 2003;95:536-44.

19 Kumar GK. Hypoxia. 3. Hypoxia and neurotransmitter synthesis. Am J Physiol Cell Physiol 2011;300:C743-51.

20 Goryo K, Torii S, Yasumoto K, et al. Tumour necrosis factor-alpha suppresses the hypoxic response by NF-kappaB-dependent induction of inhibitory PAS domain protein in PC12 cells. J Biochem 2011;150:311-18.

21 Gaber T, Dziurla R, Tripmacher R, et al. Hypoxia inducible factor (HIF) in rheumatology: low 02! See what HIF can do! Ann Rheum Dis 2005;64:971-80.

22 Muz B, Khan MN, Kiriakidis S, et al. Hypoxia. The role of hypoxia and HIF-dependent signalling events in rheumatoid arthritis. Arthritis Res Ther 2009;11:201.

$23 \mathrm{Ng} \mathrm{CT}$, Biniecka M, Kennedy A, et al. Synovial tissue hypoxia and inflammation in vivo. Ann Rheum Dis 2010;69:1389-95.

24 Trzaska KA, Rameshwar P. Dopaminergic neuronal differentiation protocol for human mesenchymal stem cells. Methods Mol Biol 2011;698:295-303.

25 Zhu H, Guo ZK, Jiang XX, et al. A protocol for isolation and culture of mesenchymal stem cells from mouse compact bone. Nat Protoc 2010;5:550-60.

26 Zhang SC, Wernig M, Duncan ID, et al. In vitro differentiation of transplantable neural precursors from human embryonic stem cells. Nat Biotechnol 2001;19:1129-33.

27 Ader R. Psychoneuroimmunology. San Diego, CA: Elsevier-Academic Press, 2007.

28 Pongratz G, Straub RH. Role of peripheral nerve fibres in acute and chronic inflammation in arthritis. Nat Rev Rheumatol 2012;10:117-26.

29 Flierl MA, Rittirsch D, Nadeau BA, et al. Phagocyte-derived catecholamines enhance acute inflammatory injury. Nature 2007;449:721-5.

30 Gozal E, Shah ZA, Pequignot JM, et al. Tyrosine hydroxylase expression and activity in the rat brain: differential regulation after long-term intermittent or sustained hypoxia. J Appl Physiol 2005;99:642-9.

31 Kato K, Yamaguchi-Yamada M, Yamamoto Y. Short-term hypoxia increases tyrosine hydroxylase immunoreactivity in rat carotid body. J Histochem Cytochem 2010;58:839-46.

32 Ghezzi P, Dinarello CA, Bianchi M, et al. Hypoxia increases production of interleukin-1 and tumor necrosis factor by human mononuclear cells. Cytokine 1991:3:189-94.

33 Konisti S, Kiriakidis S, Paleolog EM. Hypoxia-a key regulator of angiogenesis and inflammation in rheumatoid arthritis. Nat Rev Rheumatol 2012;8:153-62.

34 Tyndall A, Walker UA, Cope A, et al. Immunomodulatory properties of mesenchymal stem cells: a review based on an interdisciplinary meeting held at the Kennedy Institute of Rheumatology Division, London, UK, 31 October 2005. Arthritis Res Ther 2007:9:301.

35 Härle P, Pongratz G, Albrecht J, et al. An early sympathetic nervous system influence exacerbates collagen-induced arthritis via CD4+CD25+ cells. Arthritis Rheum 2008:58:2347-55. 


\section{A RD Anti-inflammatory effects of cell-based therapy with tyrosine hydroxylase-positive catecholaminergic cells in experimental arthritis}

Zsuzsa Jenei-Lanzl, Silvia Capellino, Frieder Kees, Martin Fleck, Torsten Lowin and Rainer H Straub

Ann Rheum Dis 2015 74: 444-451 originally published online December 2, 2013

doi: 10.1136/annrheumdis-2013-203925

Updated information and services can be found at:

http://ard.bmj.com/content/74/2/444

These include:

Supplementary Supplementary material can be found at:

Material http://ard.bmj.com/content/suppl/2013/12/02/annrheumdis-2013-2039 25.DC1

References This article cites 34 articles, 11 of which you can access for free at: http://ard.bmj.com/content/74/2/444\#BIBL

Email alerting service

Receive free email alerts when new articles cite this article. Sign up in the box at the top right corner of the online article.

$\begin{array}{cc}\text { Topic } & \text { Articles on similar topics can be found in the following collections } \\ \text { Collections } & \text { Degenerative joint disease (4641) } \\ & \text { Musculoskeletal syndromes (4951) } \\ & \text { Biological agents (545) } \\ & \text { Drugs: musculoskeletal and joint diseases (700) } \\ & \text { Osteoarthritis (931) } \\ \text { Connective tissue disease (4253) } & \text { Immunology (including allergy) (5144) } \\ & \text { Rheumatoid arthritis (3258) }\end{array}$

Notes

To request permissions go to:

http://group.bmj.com/group/rights-licensing/permissions

To order reprints go to:

http://journals.bmj.com/cgi/reprintform

To subscribe to BMJ go to:

http://group.bmj.com/subscribe/ 